\title{
Ultra performance liquid chromatography-tandem mass spectrometeric analysis of ethyl acetate fraction from saudi Lavandula coronopifolia Poir and evaluation of its cytotoxic and antioxidant activities
}

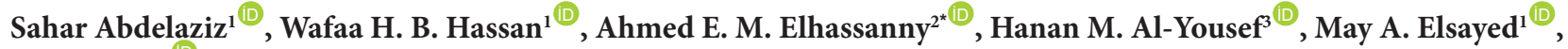 \\ Rasha Adel ${ }^{1}$ \\ ${ }^{1}$ Department of Pharmacognosy, Faculty of Pharmacy, Zagazig University, 44519 Zagazig, Egypt \\ ${ }^{2}$ Department of Pharmacology and Toxicology, Brody School of Medicine, East Carolina University, Greenville, North Carolina, 27834, USA \\ ${ }^{3}$ Department of Pharmacognosy, College of Pharmacy, King Saud University, Riyadh, Saudi Arabia
}

\section{A R T I C L E I N F O}

\section{Article Type:}

Original Article

\section{Article History:}

Received: 31 December 2019

Accepted: 21 February 2020

\section{Keywords:}

Lavandula coronopifolia Poir

UPLC-ESI-MS/MS

Antioxidant

Cytotoxicity

\begin{abstract}
A B S T R A C T
Introduction: The ethyl acetate fraction of the Saudi Lavandula coronopifolia Poir has been previously reported to have hepatoprotective activity against ethanol-induced oxidative stress. The aim of the current study was to investigate the chemical composition, cytotoxic effect, and antioxidant activities of ethyl acetate fraction of the aerial parts of Saudi L. coronopifolia Poir.

Methods: Air dried aerial parts of L. coronopifolia were extracted using $90 \%$ ethyl alcohol. The dried extract was suspended in water, defatted with light petroleum and then fractionated with ethyl acetate. The ethyl acetate fraction was subjected to ultra performance liquid chromatography-tandem mass spectrometeric (UPLC-ESI/MS/MS) analysis in a negative ionization mode. The antioxidant activity of the fraction was determined using free radical 2,2-diphyenyl-picrylhydrazyl (DPPH) scavenging assay and its cytotoxic effect against HepG2 (human hepatocarcinoma) and MCF-7 (human breast carcinoma) cells were determined using (3-(4,5-dimethylthiazol-2-yl)-2,5-diphenyltetrazolium bromide) tetrazolium (MTT) cell viability assay.

Results: The major components of the ethyl acetate fraction included carvacrol-O-diglucoside, (34.98\%) and trihydroxy ursolic acid (12.07\%). Moreover, the DPPH radical scavenging activity of ethyl acetate fraction was measured. The ethyl acetate fraction revealed an antioxidant potential with $\mathrm{EC}_{50} 17.8 \pm 1.3 \mu \mathrm{g} / \mathrm{mL}$. Additionally, he ethyl acetate fraction showed cytotoxic activity against HepG-2 and MCF-7 cells with $\mathrm{IC}_{50}=29.3 \pm 0.9 \mu \mathrm{g} / \mathrm{mL}$ and $14.6 \pm 0.3 \mu \mathrm{g} / \mathrm{mL}$, respectively.

Conclusion: The ethyl acetate fraction of the Saudi L. coronopifolia has antioxidant activity and also cytotoxic activity against breast and liver cancer cells.
\end{abstract}

Implication for health policy/practice/research/medical education:

The ethyl acetate fraction of Lavandula coronopifolia is an affordable source for compounds which have antioxidant activity and also cytotoxic activity againt heaptic and breast cancers.

Please cite this paper as: Abdelaziz S, Hassan WHB, Elhassanny AEM, Al-Yousef HM, Elsayed MA, Adel R. Ultra performance liquid chromatography-tandem mass spectrometeric analysis of ethyl acetate fraction from saudi Lavandula coronopifolia Poir and evaluation of its cytotoxic and antioxidant activities. J Herbmed Pharmacol. 2020;9(3):268-276. doi: 10.34172/jhp.2020.34.

\section{Introduction}

Genus Lavandula comprises 47 species belonging to the mint family (Lamiaceae). Lavandula species are very rich in volatile oils which make the Lavandula genus one of the most valuable group of aromatic and medicinal plants with immense economic value for pharmaceutical, cosmetics, perfumery, food and flavor industries and aromatherapy. L. coronopifolia is a woody perennial 
herb with a pleasant aroma. It is widely distributed across North Africa, Saudi Arabia and eastern Iran (1). Moreover, Lavandula contains phenolics, flavonoids, anthocyanins, sterols and tannins (2). Lavandula species have many pharmacological actions including antioxidant (3), antimicrobial (4), antidepressant $(5,6)$ and anticancer (7) activities. A previous study using the plant growing in Saudi Arabia, showed that its volatile oil component was rich in phenol-2-amino-4,6-bis (1,1-dimethylethyl), carvacrol, $n$-hexadecanoic acid, trans-2-caren-4ol, 17-pentartiacontene, caryophyllene oxide and 1-hexacosanol (8). Six major phenolic compounds were identified in the methanolic extract of the Jordanian plant via high-performance liquid chromatography (HPLC) tandem mass which included caffeic acid, rosmarinic acid, rutin, quercetin, luteolin, and hesperidin (9). L. coronopifolia has antioxidant and antimicrobial activities $(8,10)$. Our previous findings revealed that ethyl acetate fraction of $L$. coronopifolia had hepatoprotective effect against ethanol-induced oxidative stress and subsequent cell death in HepG-2 cells (11). However, the chemical composition of the ethyl acetate fraction is unknown. Therefore, in this study, the chemical composition of the ethyl acetate fraction of $L$. coronopifolia was analyzed for the first time using UPLC-ESI-MS/MS to identify its bioactive constituents. In addition, we tested the DPPH radical scavenging activity of this fraction as a measure for its antioxidant activity. The anticancer activity of $L$. coronopifolia against breast and hepatic cancer cell lines was also investigated.

\section{Materials and Methods}

Plant material

The plant was collected in March 2009, from Shaza Mountains in Saudi Arabia. Plant identity was proved by Professor Jakob Thomas from the College of Science, King Saud University. A voucher specimen (\#15799) was prepared and deposited at the herbarium unit of Pharmacognosy Department, College of Pharmacy, King Saud University. The aerial parts of $L$. coronopifolia were ground after air-drying, into coarse particles till use.

\section{Extraction of plant material}

Air dried aerial parts (300 g) of L. coronopifolia were extracted by $90 \%$ ethyl alcohol till complete exhaustion to afford (30 g) of dry extract. The dried extract was suspended in water, defatted with light petroleum and then fractionated with ethyl acetate to afford $3.5 \mathrm{~g}$ of ethyl acetate fraction.

\section{UPLC- ESI- MS/MS analysis}

The ethyl acetate fraction of L. coronopifolia was prepared as solution of $100 \mu \mathrm{g} / \mathrm{mL}$ using HPLC grade methanol, filtered using a membrane disc filter $(0.2 \mu \mathrm{m})$ then subjected to LC-ESI-MS analysis as described by (12).
Antioxidant assay

The antioxidant activity of the ethyl acetate fraction of L. coronopifolia was determined at the Regional Center for Mycology and Biotechnology (RCMB) at AlAzhar University using the free radical 2,2-diphyenylpicrylhydrazyl (DPPH) scavenging assay, as described by (13).

Cell culture and cytotoxicity assay

HepG-2 (Human hepatocarcinoma) and MCF-7 (human breast carcinoma) cells were obtained from VACSERA Tissue Culture Unit and maintained in DMEM supplemented with $10 \%$ FBS and $100 \mu \mathrm{g} / \mathrm{mL}$ penicillinstreptomycin-amphotericin B solution. The cytotoxic effects of the ethyl acetate fraction of L. coronopifolia against HepG-2 and MCF-7 cells were determined using the MTT cell viability assay as described by (14).

\section{Results}

Characterization of the components of the ethyl acetate fraction of aerial parts of $L$. coronopifolia.

Sixty compounds were tentatively identified by UPLCESI-MS/MS (negative ionization mode) from the ethyl acetate fraction of L. coronopifolia (Figure 1). Tables 1 and 2 show the list of the identified compounds along with their retention time $\left(\mathrm{R}_{\mathrm{t}}\right)$, detected mass $(\mathrm{M}-\mathrm{H})$ and MS/ MS fragment ions. UPLC-ESI-MS/ MS chromatograms of some identified compounds are shown in Figure 2. Eleven phenolic acids were identified $(2,3,4,5,6,7,8$, 28, 34, 39 and 41). Most of the identified phenolic acids belong to the group of hydroxycinnamate derivatives, namely caftaric acid and its isomers, chicoric acid, caffeic, rosmarinic acid, and different salvianolic acids. Some of these compounds were previously reported in Lavandula species as salvianolic acid B, rosmarinic acid and caffeic acid $(15,16)$. Six compounds $(4,25,35,38,40$ and 42$)$ were identified as phenolic acid derivatives. Twenty-four triterpenoids were detected as shown in Tables 1 and 2. All of the detected compounds were ursolic acid derivatives. These compounds include dihydroxy, trihydroxy, tetrahydroxy, carboxy, monomethoxy, monomethoxy

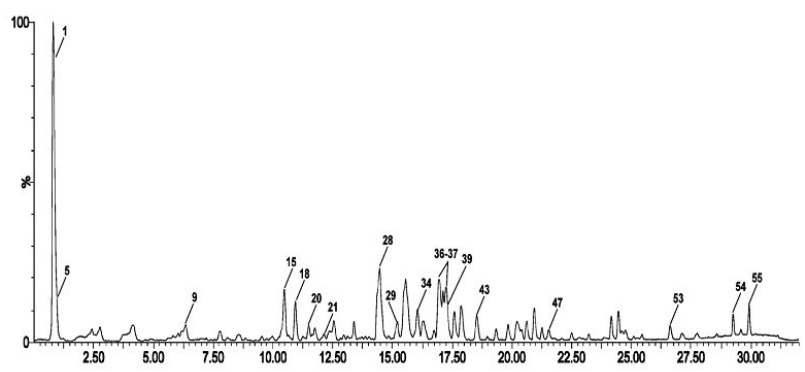

Figure 1. Ultra performance liquid chromatography-tandem mass spectrometeric (UPLC-ESI-MS) chromatograms of ethyl acetate fraction of Lavandula coronopifolia. 
Table 1. Major compounds identified in ethyl acetate (EA) fraction of Lavandula coronopifolia Poir using UPLC-ESI-MS/MS

\begin{tabular}{|c|c|c|c|c|c|c|}
\hline No. & Tentative identification & $R_{t}(\min )$ & MS $^{1}$ & $\mathrm{MS}^{2}$ & EA (\%) & Ref. \\
\hline 1 & Carvacrol-O- diglucoside & 0.80 & 473 & $149(100 \%)$ & 34.98 & (17) \\
\hline 2 & Chicoric acid & 2.42 & 473 & 295, $179.0(100 \%), 149$ & 0.53 & (18) \\
\hline 3 & Caffeic acid & 6.28 & 179 & $134.9(100 \%)$ [M-H COOH] & 0.50 & (15) \\
\hline 4 & Hydroxyl benzoic acid derivative & 8.78 & 355 & $137(100 \%), 78$ & 0.60 & (19) \\
\hline 5 & Rosmarinic acid & 10.24 & 359 & $196.9,160.1(100 \%)$ & 2.88 & $(15,20)$ \\
\hline 6 & Azelaic acid & 10.79 & 187 & $170,125(100 \%)$ & 0.58 & (21) \\
\hline 7 & Azelaic acid isomer & 10.94 & 187 & $171,125(100 \%)$ & 2.42 & (21) \\
\hline 8 & Salvianolic acid C & 12.36 & 491 & $293(100 \%)$ & 0.20 & $(22,23)$ \\
\hline 9 & Salvianolic acid $A$ isomer & 12.56 & 493 & $295.1,197.1,178.9,134.9(100 \%)$ & 1.02 & $(20)$ \\
\hline 10 & Tetrahydroxy urosolic acid & 13.76 & 519 & $\begin{array}{l}501.0(100 \%)[\mathrm{M}-\mathrm{H}-18], 455,426,407,379,325,289,223, \\
159\end{array}$ & 0.70 & (24) \\
\hline 11 & Tetrahydroxy urosolic acid isomer & 14.10 & 519 & $\begin{array}{l}501.0 \text { (100\%) [M-H-18], 455, 426, 407, 379, 325, 289, 223, } \\
159\end{array}$ & 4.38 & (24) \\
\hline 12 & Tetrahydroxy urosolic acid isomer & 14.34 & 519 & 501 [M-H-18], 473, 455, 407, 391 (100\%) & 2.12 & $(24)$ \\
\hline 13 & Trihydroxy urosolic acid & 15.18 & 503 & $485\left[\mathrm{M}-\mathrm{H}-\mathrm{H}_{2} \mathrm{O}\right], 456,439,393$ (100\%), 377, 357 & 0.60 & $(24)$ \\
\hline 14 & Umbelliferone rutinoside & 15.29 & 469 & $161(100 \%)$ & 0.53 & $(25)$ \\
\hline 15 & $\begin{array}{l}2 \alpha, 3 \beta, 19 \alpha, 2 \beta \text { trihydroxy } \\
\text { urosolic acid isomer }\end{array}$ & 15.57 & 503 & $485\left[\mathrm{M}-\mathrm{H}-\mathrm{H}_{2} \mathrm{O}\right], 456,439,393$ & 4.86 & $(24)$ \\
\hline 16 & Pimarane diterpene & 15.82 & 329 & $\begin{array}{l}293.3,229.1,210.9,193.3,183.1,171.4,167.3,154.8,139.3 \\
(100 \%), 127.4,98.7,71.3,56.9,44.8,41.3\end{array}$ & 0.65 & $(26,27)$ \\
\hline 17 & Luteolin derivative & 15.88 & 519 & $285(100 \%)$ & 0.50 & $(28)$ \\
\hline 18 & $\begin{array}{l}2 \alpha, 3 \beta, 19 \alpha, 2 \beta \text { trihydroxy } \\
\text { urosolic acid }\end{array}$ & 16.60 & 503 & $485\left[\mathrm{M}-\mathrm{H}-\mathrm{H}_{2} \mathrm{O}\right], 441,409,393$ (100\%), 375, 359 & 3.42 & $(24)$ \\
\hline 19 & $\begin{array}{l}2 \alpha, 3 \beta, 19 \alpha, 2 \beta \text { trihydroxy } \\
\text { urosolic acid isomer }\end{array}$ & 16.85 & 503 & $485\left[\mathrm{M}-\mathrm{H}-\mathrm{H}_{2} \mathrm{O}\right], 455,441,358.8,393.2(100 \%)$ & 3.79 & $(24)$ \\
\hline 20 & $\begin{array}{l}2 \alpha, 3 \beta, 19 \alpha, 2 \beta \text { trihydroxy } \\
\text { urosolic acid isomer }\end{array}$ & 17.00 & 503 & $455.6(100 \%), 436.8,419.8,395.0,377.0$ & 0.55 & (24) \\
\hline 21 & $\begin{array}{l}\text { Monohydroxylmono-methoxy } \\
\text { urosolic acid }\end{array}$ & 17.11 & 501 & 501 (100\%) 455 (100\%), 421, 388, 337, 305, 225, 59 & 3.19 & (29) \\
\hline 22 & Urosolic acid derivative & 17.17 & 517 & $455,437,419,395,377$ & 0.70 & $(29)$ \\
\hline 23 & Urosolic acid derivative & 17.25 & 547 & 501 (100\%) [M-H-COOH], 455 & 0.80 & (29) \\
\hline 24 & Methoxy urosolic acid & 17.72 & 485 & $485(100 \%), 439(100 \%)[\mathrm{M}-\mathrm{HCOOH}], 391\left[\mathrm{M}-\mathrm{H}_{2} \mathrm{O}-\mathrm{OCH}_{3}\right]$ & 4.13 & (29) \\
\hline 25 & Caftaric acid derivative & 18.54 & 487 & 311,179 & 2.10 & (19) \\
\hline 26 & $\begin{array}{l}\text { Asiatic acid } \\
\text { dihydroxy urosolic acid }\end{array}$ & 20.70 & 487 & 487 (100\%), 409 [M-H-HCOOH, HCH2OH] , 373 & 0.56 & $(24,29)$ \\
\hline 27 & Urosolic acid methyl ester & 20.92 & 469 & $451(100 \%)\left[\mathrm{M}-\mathrm{H}-\mathrm{H}_{2} \mathrm{O}\right], 407,373,309$ & 2.69 & \\
\hline 28 & Salvianolic acid G & 23.86 & 339 & $295(100 \%)$ & 2.87 & (23) \\
\hline 29 & 9- Hydroxy palmitic acid & 23.92 & 271 & $\begin{array}{l}225.2(100 \%)[\mathrm{M}-\mathrm{H} 46], 197.5\left[-\mathrm{C}_{2} \mathrm{H}_{4}\right], 127.0\left[-\mathrm{C}_{5} \mathrm{H}_{10}\right], 97.2 \\
{[-\mathrm{CHOH}]}\end{array}$ & 3.43 & (30) \\
\hline 30 & $\begin{array}{l}\text { Asiatic acid dihydroxy urosolic } \\
\text { acid isomer }\end{array}$ & 24.66 & 487 & 487 (100\%), 409 [M-H-HCOOH, HCH2OH] , 373 & 0.98 & $(24,29)$ \\
\hline 31 & Palmitic acid 1 & 25.95 & 255 & $140(100 \%)$ & 1.11 & (4) \\
\hline 32 & Oleic acid & 26.41 & 281 & $111(100 \%)$ & 0.93 & $(4,31)$ \\
\hline \multirow[t]{2}{*}{33} & Long chain fatty acid & 29.80 & 383 & 337 [M-H-COOH], 309 [M-H-COOH-C2H4] & 2.89 & - \\
\hline & Total \% of area under peak & & & & $89.52 \%$ & \\
\hline
\end{tabular}

monohydroxy ursolic acid and other derivatives. One pimarane diterpene was detected in the ethyl acetate fraction. Moreover, six compounds were identified as flavonoids including 17, 43, 44, 45, 46 and 54. Two coumarins (peaks14 and 37), palmitic acid and oleic acid
(Peaks 6 and 7), and carvacrol-O-diglucoside (Peaks 1) were also detected.

Antioxidant activity and anticancer activity

In this study, the antioxidant activity of the ethyl acetate 
Table 2. Minor compounds identified in ethyl acetate (EA) fraction of Lavandula coronopifolia Poir using UPLC-ESI-MS/MS

\begin{tabular}{|c|c|c|c|c|c|c|}
\hline No. & Tentative identification & $R_{t}(\min )$ & $\mathrm{MS}^{1}$ & $\mathrm{MS}^{2}$ & EA (\%) & Reference \\
\hline 34 & Salvianolic acid B isomer & 0.89 & 717 & 519 (100\%), 339, 313, 179, & $\checkmark$ & (20) \\
\hline 35 & Caffeic acid diglucoside & 1.32 & 503 & 341 (100\%) [M-H-162], 179 & $\checkmark$ & \\
\hline 36 & Syringic acid derivative & 6.01 & 501 & $197(100 \%), 135$ & $\checkmark$ & - \\
\hline 37 & Esculetin - $O$-glycoside & 6.38 & 339 & $177.0(100 \%)$ & $\checkmark$ & (32) \\
\hline 38 & Homovanillic acid rhamnoside & 6.79 & 327 & $181[\mathrm{M}-\mathrm{H}-146]$ & $\checkmark$ & - \\
\hline 39 & Chicoric acid isomer & 7.90 & 473 & $295,179(100 \%), 115$ & $\checkmark$ & (18) \\
\hline 40 & Hydroxy caffeic acid rutinoside & 9.35 & 503 & $195[\mathrm{M}-\mathrm{H}-308]$ & $\checkmark$ & - \\
\hline 41 & Caftaric acid isomer & 9.82 & 311 & $\begin{array}{l}265.0 \text { (100\%) [M - H -COOH], } 179 \text { [M - H - tartaric] } \\
149.0 \text { [M-H- caffeoyl] }\end{array}$ & $\checkmark$ & (18) \\
\hline 42 & Ferulic acid derivative & 10.55 & 383 & $193(100 \%), 137$ & $\checkmark$ & - \\
\hline 43 & Naringenin derivative & 10.66 & 519 & $271.2(100 \%)$ & $\checkmark$ & (33) \\
\hline 44 & Naringenin derivative & 11.58 & 469 & $271(100 \%), 177$ & $\checkmark$ & (33) \\
\hline 45 & Apigenin acetyl glucoside & 11.69 & 473 & $269(100 \%)$ & $\checkmark$ & (34) \\
\hline 46 & Chrysoeriol acetyl hexoside & 12.15 & 503 & 299, 285 (100\%) & $\checkmark$ & (35) \\
\hline 47 & Urosolic acid derivative & 12.49 & 517 & $\begin{array}{l}472.8(100 \%), 498.5,455,440.7,336.9,293.0,322.7 \\
277.5,205.3,143.9\end{array}$ & $\checkmark$ & (29) \\
\hline 48 & Carboxy urosolic acid & 13.56 & 499 & $455.3(100 \%)$ [M-H-COOH], 436.9 [urosolic acid- $\mathrm{H}_{2} \mathrm{O}$ ] & $\checkmark$ & \\
\hline 49 & Dihydroxy monomethoxy urosolic acid & 13.59 & 517 & $455(100 \%), 407$ & $\checkmark$ & (29) \\
\hline 50 & $\begin{array}{l}\text { Dihydroxy monomethoxy urosolic acid } \\
\text { isomer }\end{array}$ & 13.70 & 517 & 455.0 (100\%), 472.3 [M-H-COOH], 453.2, 441.8, 423.2 & $\checkmark$ & (29) \\
\hline 51 & Quercetin derivative & 14.90 & 503 & $301.0(100 \%)$ & $\checkmark$ & (24) \\
\hline 52 & Urosolic acid derivative & 15.51 & 517 & $455(100 \%)$ & $\checkmark$ & $(29)$ \\
\hline 53 & Urosolic acid derivative & 16.33 & 485 & $467.3,425.3,375.1,359.5,259.8$ & $\checkmark$ & $(24)$ \\
\hline 54 & Isorhamnetin derivative & 16.87 & 517 & $315(100 \%), 255.3$ & $\checkmark$ & - \\
\hline 55 & Methoxy urosolic acid & 16.93 & 485 & 455 (100\%) [M-H-OMe], 365.4, 422.7 & $\checkmark$ & (29) \\
\hline 56 & Carboxy urosolic acid & 17.31 & 499 & $454.6[\mathrm{M}-\mathrm{H}-\mathrm{COOH}], 437.5,373.9,235.6,185.2$ & $\checkmark$ & \\
\hline 57 & Tormentic acid & 17.34 & 487 & 469 [M-H-H2O], 393 (100\%) & $\checkmark$ & $(36)$ \\
\hline 58 & Trihydroxy urosolic acid isomer & 17.65 & 503 & 485.0 (100\%), 455.6, 436.8, 419.8, 395.0, 377.0 & $\checkmark$ & (24) \\
\hline 59 & Dihydroxy urosolic acid & 18.11 & $\begin{array}{l}487 \\
(100 \%)\end{array}$ & $\begin{array}{l}455.5(100 \%), 468.8,467.1,421.0,409,392.9,374.8 \\
325.2,70.8,59.0,57.6\end{array}$ & $\checkmark$ & (29) \\
\hline 60 & Urosolic acid derivative & 24.13 & 501 & $455(100 \%)$ & $\checkmark$ & (29) \\
\hline
\end{tabular}

fraction of L. coronopifolia was compared to ascorbic acid, a well-known antioxidant. The fraction showed concentration-dependent antioxidant activity as demonstrated by increase in its DPPH radical scavenging activity (Figure 3). The concentration of the fraction which resulted in 50\% DPPH scavenging activity (EC50 $=17.8 \pm$ $0.8 \mu \mathrm{g} / \mathrm{mL})$ was similar to ascorbic acid $\left(\mathrm{EC}_{50}=14.2 \pm 0.5\right.$ $\mu \mathrm{g} / \mathrm{mL})$.

We also investigated the anticancer activity of the fraction of L. coronopifolia against HepG-2 (hepatocellular carcinoma) and MCF-7 (breast carcinoma) in comparison to cisplatin, a well-known anticancer agent. As shown in Figure 4, the fraction showed dose-dependent cytotoxic activity against HepG-2 and MCF-7 cells. In addition, the $\mathrm{IC}_{50}$ values (the concentration which inhibits $50 \%$ of the cell viability) of the fraction in HepG-2 and MCF-7 cells were $14.6 \pm 0.3 \mu \mathrm{g} / \mathrm{mL}$ and $29.3 \pm 0.9 \mu \mathrm{g} / \mathrm{mL}$, respectively (Table 3).

\section{Discussion}

In this study, we analyzed the chemical composition of the ethyl acetate fraction of L. coronopifolia for the first time using UPLC-ESI-MS/MS to identify its bioactive constituents responsible for their cytotoxic and antioxidant activities. Some of the identified compounds as caffeic acid, rosmarinic acid (9), and Pimarane diterpene derivatives $(26,27)$ were reported before in $L$. coronopifolia.

In ethyl acetate fraction of $L$. coronopifolia, phenolic acids and their derivatives were identified based on their MS fragmentation and previous studies. The MS/MS 


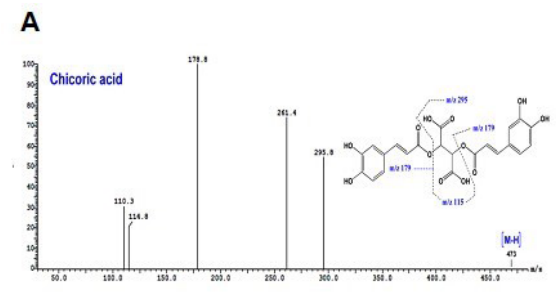

E
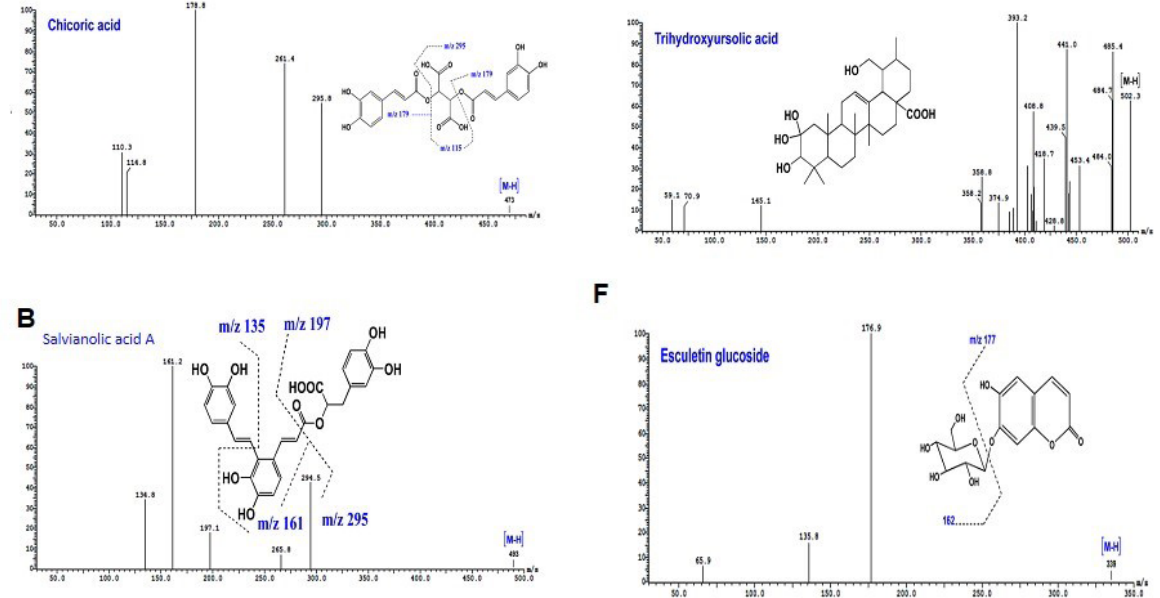

$\mathbf{F}$
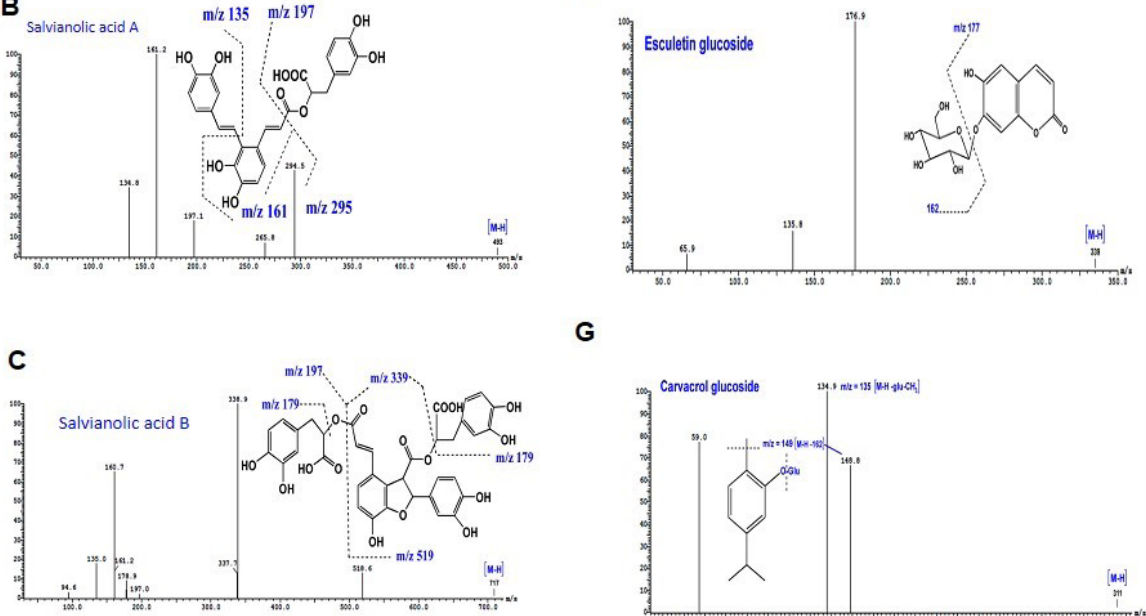

G
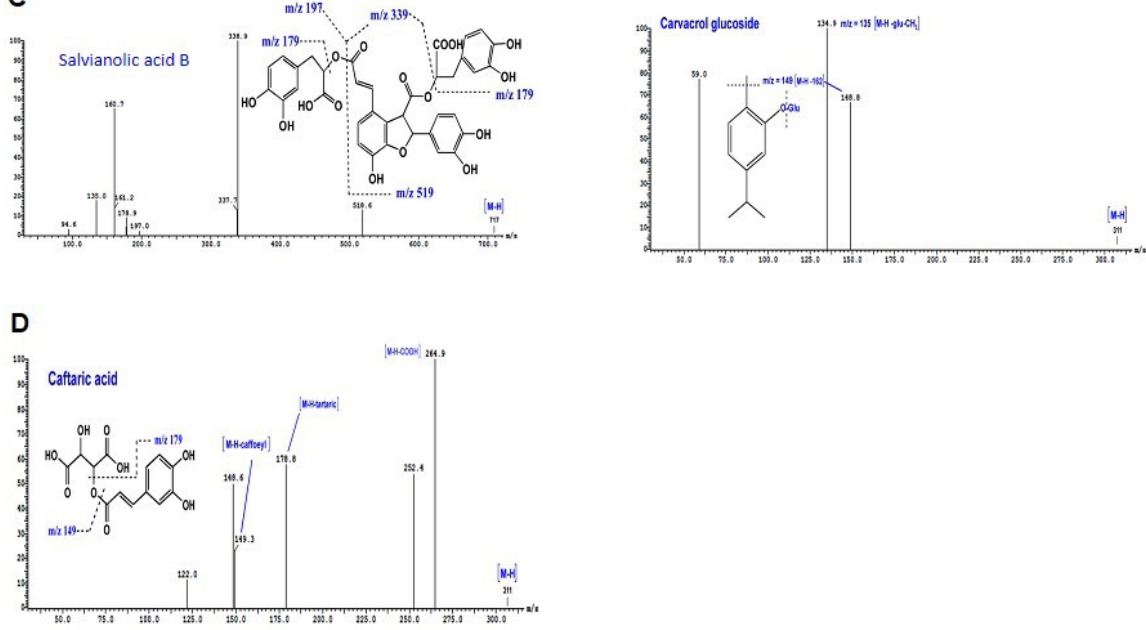

Figure 2. Ultra performance liquid chromatography-tandem mass spectrometeric (UPLC-ESI-MS) chromatograms of some identified compounds from Lavandula coronopifolia.

fragmentation of phenolic acids showed the presence of caffeic hydroxycinnamic acid or tartaric hydroxycinnamic acid moieties (37). Peak 3 with molecular ion peak at $\mathrm{m} / \mathrm{z}$ 179 [M-H] was identified as caffeic acid (20). Peaks 2 and 39 showed $\mathrm{M}-\mathrm{H}$ at $\mathrm{m} / \mathrm{z} 473$ and were identified as chicoric acid isomers (Figure 2A) (18). Peak 4 was identified as rosmarinic acid. It was found as a major component in the ethyl acetate fraction $(2.88 \%)$ and was previously reported in L. pedunculata (20). Peak 34 showed an [M$\mathrm{H}]$ ion at $m / z 717$ as well as fragments ion at $m / z 519,339$ (100\%), 197, 179 which were characteristic for salvianolic acid B (Figure 2C). Peak 41 showed [M-H] - molecular ion at $\mathrm{m} / z 311$ and fragment ions at $\mathrm{m} / z 265.0$ (100\%) [M $\mathrm{H}-\mathrm{COOH}$ ], 179 [M-H-tartaric], 149.0 [M-H-caffeoyl] which coincided with the loss of mass of caffeic acid and tartaric acid, and was thus identified as caftaric acid isomers (Figure 2D) (18). Phenolic acid derivatives such as compounds 4 and 40 with $[\mathrm{M}-\mathrm{H}]^{-}$at $\mathrm{m} / z 355$ and 503 and $\mathrm{MS}^{2}$ base peak fragments at $\mathrm{m} / \mathrm{z} 137$ and 195 consequently were characterized as hydroxyl benzoic acid derivative
(38) and hydroxy caffeic acid rutinoside.

Triterpenes, hydroxylated ursolic acid, and ursolic acid derivatives were also identified in ethyl acetate fraction of L. coronopifolia. Dihydroxy, trihydroxy, tetrahydroxy, carboxy, monomethoxy, monomethoxy monohydroxy

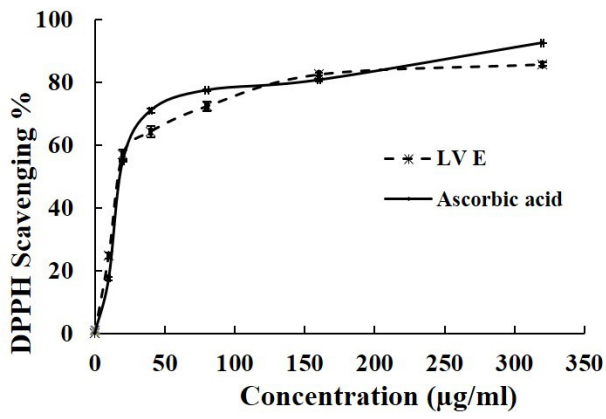

Figure 3. 2,2-diphyenyl-picrylhydrazyl (DPPH) radical scavenging activity of Lavandula coronopifolia ethyl acetate fraction (LV E). Data are presented as averages \pm standard deviations from three experiments. 
A
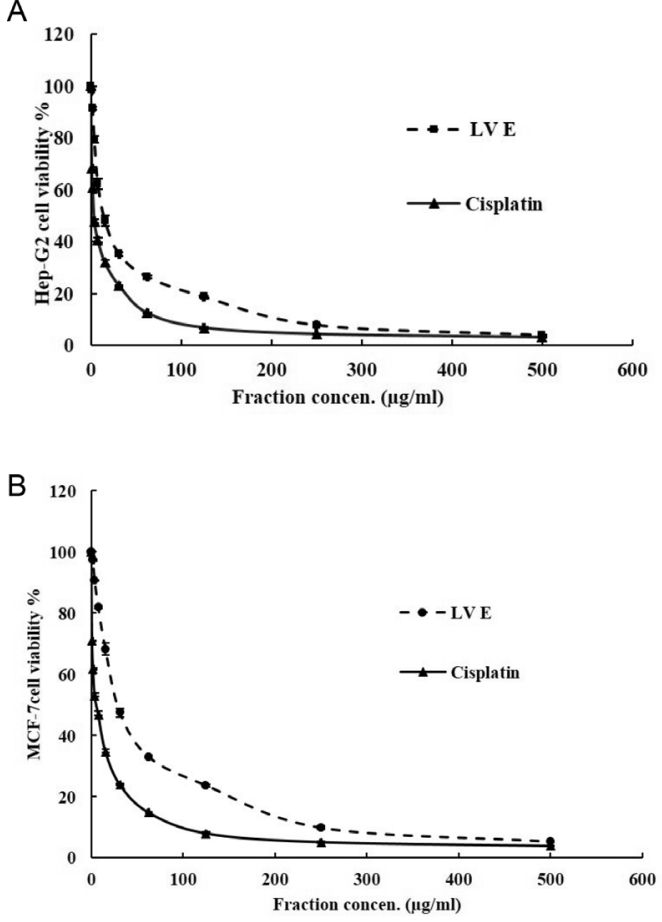

Figure 4. Cytotoxic activity of different concentrations of Lavandula coronopifolia ethyl acetate fraction (LV E) against HepG-2 cells (A) and MCF -7 cells. Data are presented as averages \pm standard deviations from three experiments.

ursolic acid and other derivatives were detected. Peaks 26, 30, 57 and 59 (showed $[\mathrm{M}-\mathrm{H}]^{-}$ions at $\mathrm{m} / z$ 487, the MS/MS spectrum exhibited a neutral loss of carboxyl and hydroxymethyl group, leading to form the fragment ion at $m / z 409$ characteristic of dihydroxy ursolic acid which is known as asiatic acid (29). Dihydroxy ursolic acid was previously reported in L. canariensis (24). Peaks 13, 15, $18,19,20$ and 58 were identified as trihydroxy ursolic acid isomers (Figure 2E). MS ${ }^{1}$ of these peaks showed the same molecular ion peak at $m / z 503[\mathrm{M}-\mathrm{H}]$ and $\mathrm{MS}^{2}$ fragment ions at $m / z 485$ [M-H-H $\mathrm{H}_{2} \mathrm{O}$, 441[M-H-H $\mathrm{H}_{2} \mathrm{O}-\mathrm{COOH}$ ], 409, $393(100 \%), 375,359$ which are characteristic fragments for polyhydroxylated ursolic acid isomers (29). The peaks $10,11,12$ were identified as tetrahydroxyursolic acid isomers from their $\mathrm{MS}^{1}$ which showed the same molecular ion peak $\mathrm{m} / \mathrm{z} 519[\mathrm{M}-\mathrm{H}]$ and $\mathrm{MS}^{2}$ fragment ions at $\mathrm{m} / z$ 501.0 [M-H- $\mathrm{H}_{2} \mathrm{O}$ ], 455 [ursolic acid], 426, 407, 379, 325, 289, 223 and 159 (29). Polyhydroxy ursolic acid derivatives were previously reported in Lavandula species (24). Peak 27 with MS $^{1}[\mathrm{M}-\mathrm{H}]$ at $m / z 469$ and $\mathrm{MS}^{2}$ fragment ions at $m / z 451$ (100\%) [M-H-H $2 \mathrm{O}$ ], 407, 373, 309 was characteristic fragmentation of ursolic acid methyl ester. Peaks 47, 49, 50 and 52 showed the same $[\mathrm{M}-\mathrm{H}]$ at $\mathrm{m} / z$ 517 and $\mathrm{MS}^{2}$ fragment ion at $m / z 455$ was identified as ursolic acid derivatives (may be dihydroxy monomethoxy ursolic acid isomers) (29). Peak 55 with deprotonated molecular ion peak at $m / z 485$ with $\mathrm{MS}^{2}$ fragment ions at $m / z 455(100 \%)$ [M-H-OMe] is characteristic for methyl
Table 3 Half maximum inhibitory concentration $\left(\mathrm{IC}_{50}\right)$ of of ethyl acetate (LV E) fraction of Lavandula coronopifolia Poir against HepG-2 and MCF-7 cells after the treatment for 48 hours, as measured by MTT assay

\begin{tabular}{lcc}
\hline \multirow{2}{*}{ Cell line } & \multicolumn{2}{c}{ Tested fraction } \\
\cline { 2 - 3 } & \multicolumn{2}{c}{$\mathrm{IC}_{50}(\mu \mathrm{g} / \mathrm{mL}) \pm \mathrm{SD}$} \\
\cline { 2 - 3 } & $\mathrm{LV} \mathrm{E}$ & Cisplatin \\
\hline HepG-2 (Hepatocellular carcinoma) & $14.6 \pm 0.3$ & $3.67 \pm 3.8$ \\
MCF-7 (Breast carcinoma) & $29.3 \pm 0.9$ & $5.71 \pm 8.1$ \\
\hline
\end{tabular}

The data are presented as $\mu \mathrm{g} / \mathrm{mL}$. These are the mean of three determinations.

ursolic acid. In addition, peaks 48 and 56 with the same deprotonated molecular ion peaks at $m / z 499$ [M-H] with $\mathrm{MS}^{2}$ fragment ions at $m / z 455.3$ (100\%) [M-H-COOH], were identified as carboxy ursolic acid (29). Peaks 21-24 with $\mathrm{MS}^{1}[\mathrm{M}-\mathrm{H}]$ at $m / z 501517,547$ and 485 respectively were identified as mono-hydroxy mono-methoxy ursolic acid, ursolic acid derivative, an ursolic acid derivative and methoxy ursolic acid, respectively. Fragmentation of peak 60 gave molecular ion peak at $m / z 501$ and main base peak fragment ion at m/z 455 (ursolic acid), by loss of $46 \mathrm{Da}$; it was tentatively characterized as ursolic acid derivative (29).

In the present study, one pimarane diterpene was detected in the ethyl acetate fraction. Peak16 with deprotonated molecular ion peak at $\mathrm{m} / \mathrm{z} 329$ and $\mathrm{MS}^{2}$ fragment ions at $m / z 293.3,139.3$ (100\%), indicates the presence of pimarane diterpene derivative related to the previously reported in L. multifida $(26,27)$. Mass fragmentations obtained by ESI MS/MS at $m / z 285,269$, $301,317,315$ and 299 are characteristic for the aglycones of kaempferol, apigenin, quercetin, myricetin, isorhamnetin and chrysoeriol respectively. The loss of 204, 189 and 176 allow the identification of acetyl hexoside, acetyl rhamnoside, and glucuronide, respectively. Peaks 17 and 54 exhibited [M-H] at $m / z 519$ and 517 respectively and MS/MS base peak fragment ions at $m / z 285$, and 315 [M-H176] respectively, thus these compounds were tentatively identified as luteolin and isorhamnetin derivative (39), respectively. Luteolin was previously reported in Lavender (40).

Coumarins, fatty acids and their derivatives and volatile components were detected in the ethyl acetate fraction. Peak 14 was identified as umbelliferone-O-rutinoside from its [M-H] at $m / z 469$ and $\mathrm{MS}^{2}$ fragment ion at $m / z 161$ (100\%) which showed the loss of $308 \mathrm{mu}$ corresponding to rutinose (25). The peak 37 displayed $[\mathrm{M}-\mathrm{H}]^{-}$ion at $\mathrm{m} / \mathrm{z}$ 339 and was identified as esculetin-O-glycoside (Figure 2F) (32). Peaks 31 and 32, showed [M-H] at 255 and 281 respectively and $\mathrm{MS}^{2}$ base peak fragment ions at $\mathrm{m} / z 140$ and 111 were identified as palmitic acid and oleic acid, respectively $(4,41)$. Palmitic acid was previously detected in L. officinalis leaves (4). Peak 29 with $\mathrm{MS}^{1}$ at $\mathrm{m} / \mathrm{z} 271$ and $\mathrm{MS}^{2}$ fragment ions at $m / z 225.2$ (100\%) [M-H-46], 197.5 $\left[-\mathrm{C}_{2} \mathrm{H}_{4}\right], 127.0\left[-\mathrm{C}_{5} \mathrm{H}_{10}\right], 97.2[-\mathrm{CHOH}]$ were identified as 
9- hydroxy palmitic acid (30). Peak 33 shows $\mathrm{MS}^{1}$ at $\mathrm{m} / z$ 383 [M-H] 337[M-H-COOH], 309[M-H-COOH-C $\left.\mathrm{H}_{4}\right]$ thus it was tentatively identified as a long chain fatty acid. ESI-MS/MS analysis of peaks 1 showed $\mathrm{MS}^{1}$ molecular ion peaks at $m / z 473$ and ESI-MS/MS base peak fragment ion at $\mathrm{m} / \mathrm{z}$ 149. Thus, this compound was identified as carvacrol-O-diglucoside (17).

An antioxidant agent can reduce or inhibit oxidative damage by scavenging free radicals. These radicals and other reactive oxygen species play a significant role in the pathogenesis of many diseases $(42,43)$. Numerous plant extracts including those belonging to the Lamiaceae family have been reported to have antioxidant activity. In this study, the ethyl acetate fraction of L. coronopifolia showed concentration-dependent antioxidant activity as demonstrated by increase in its DPPH radical scavenging activity. These results support the previous literature about the antioxidant potential of this plant and many other Lavandula species $(3,9)$. The antioxidant activity of ethyl acetate fraction can be due to carvacrol and ursolic acid. These compounds have been reported to have antioxidant activity in previous studies $(44,45)$.

Cancer is the second leading cause of death all over the world. Conventional cancer therapies are associated with serious side effects. Hence, there is an increasing demand to utilize alternative approaches to treat cancer. Plantsderived compounds have been reported to have activity against different types of cancer $(46,47)$. Importantly, these compounds are relatively not associated with toxic side effects (48). In this study, the ethyl acetate fraction of L. coronopifolia showed dose-dependent cytotoxic activity against HepG-2 (hepatocellular carcinoma) and MCF7 (breast carcinoma) cells. Consistent with our results, previous studies demonstrated the anticancer potential of Lavandula species $(49,50)$. The cytotoxic activity of ethyl acetate fraction can be attributed to the presence of carvacrol and ursolic acid. In accordance with our results, previous studies have shown that these compounds have antitumor activity against different types of cancer including breast and liver cancers (51-53).

\section{Conclusion}

Our findings revealed that the ethyl acetate fraction of L. coronopifolia has antioxidant and cytotoxic activities. These activities may be attributed to the high percentage of phenolic compounds and polyhydroxylated ursolic acid derivatives.

\section{Acknowledgments}

The authors thank Prof Dr. Jakob Thomas, College of Science, King Saud University, Riyadh, Kingdom of Saudi Arabia (KSU) for the plant identification.

\section{Authors' contributions}

All authors made considerable contributions to the manuscript. SA and WHBH designed the study. SA, WHBH, HMA, MAE and RA performed the experiments. SA, WHBH and AEME interpreted the results. SA and AEME wrote the manuscript. All authors revised the manuscript and confirmed it for publication

\section{Conflict of interests}

The authors declare that there are no conflicts of interest.

\section{Ethical considerations}

This study was only performed on commercially available cell lines and no human specimens or animal models were examined. All ethical issues have been approved by the research ethics committee of Faculty of Pharmacy, Zagazig University (P-1-12-2016).

\section{Funding/Support}

The authors did not receive any funding from profit or non-profit organizations to support this research.

\section{References}

1. Aprotosoaie AC, Gille E, Trifan A, Luca VS, Miron A. Essential oils of Lavandula genus: a systematic review of their chemistry. Phytochem Rev. 2017;16(4):761-99.

2. Prusinowska R, Śmigielski KB. Composition, biological properties and therapeutic effects of lavender (Lavandula angustifolia L). A review. Herba Pol. 2014;60(2):56-66.

3. Messaoud C, Chograni H, Boussaid M. Chemical composition and antioxidant activities of essential oils and methanol extracts of three wild Lavandula L. species. Nat Prod Res. 2012;26(21):1976-84.

4. Shafaghat A, Salimi F, Amani-Hooshyar V. Phytochemical and antimicrobial activities of Lavandula officinalis leaves and stems against some pathogenic microorganisms. J Med Plants Res. 2012;6(3):455-60.

5. Kageyama A, Ueno T, Oshio M, Masuda H, Horiuchi H, Yokogoshi H. Antidepressant-like effects of an aqueous extract of lavender (Lavandula angustifolia Mill.) in rats. Food Sci Technol Res. 2012;18(3):473-9.

6. Rahmati B, Kiasalari Z, Roghani M, Khalili M, Ansari F. Antidepressant and anxiolytic activity of Lavandula officinalis aerial parts hydroalcoholic extract in scopolamine-treated rats. Pharm Biol. 2017;55(1):958-65.

7. Shaikh R, Pund M, Dawane A, Iliyas S. Evaluation of anticancer, antioxidant, and possible anti-inflammatory properties of selected medicinal plants Used in Indian Traditional Medication. J Tradit Complement Med. 2014;4(4):253-7. doi: 10.4103/2225-4110.128904.

8. Hassan W, El Gamal A, El-Sheddy E, Al-Oquil M, Farshori $\mathrm{N}$. The chemical composition and antimicrobial activity of the essential oil of Lavandula coronopifolia growing in Saudi Arabia. J Chem Pharm Res. 2014;6:604-515.

9. Al Khateeb W, Kanaan R, El-Elimat T, Alu'datt M, Lahham J, El-Oqlah A. In vitro propagation, genetic stability, and secondary metabolite analysis of wild lavender (Lavandula coronopifolia Poir.). Hortic Environ Biotechnol. 2017;58(4):393-405.

10. Ait Said L, Zahlane K, Ghalbane I, El Messoussi S, 
Romane A, Cavaleiro C, et al. Chemical composition and antibacterial activity of Lavandula coronopifolia essential oil against antibiotic-resistant bacteria. Nat Prod Res. 2015;29(6):582-5.

11. Farshori NN, Al-Sheddi ES, Al-Oqail MM, Hassan WH, AlKhedhairy AA, Musarrat J, et al. Hepatoprotective potential of Lavandula coronopifolia extracts against ethanol induced oxidative stress-mediated cytotoxicity in HepG2 cells. Toxicol Ind Health. 2015;31(8):727-37.

12. Hassan WH, Abdelaziz S, Al Yousef HM. Chemical Composition and Biological Activities of the Aqueous Fraction of Parkinsonea aculeata L. Growing in Saudi Arabia. Arab J Chem. 2019;12(3):377-87.

13. Al Khateeb W, Kanaan R, El-Elimat T, Alu'datt M, Lahham J, El-Oqlah A. In vitro propagation, genetic stability, and secondary metabolite analysis of wild lavender (Lavandula coronopifolia Poir.). Horticulture, Environment, and Biotechnology. 2017;58(4):393-405.

14. Ramos-Silva A, Tavares-Carreon F, Figueroa M, De la Torre-Zavala S, Gastelum-Arellanez A, Rodriguez-Garcia A, et al. Anticancer potential of Thevetia peruviana fruit methanolic extract. BMC Complement Altern Med. 2017;17(1):241. doi: 10.1186/s12906-017-1727-y.

15. Turgut AC, Emen FM, Canbay HS, Demirdöğen RE, Çam $\mathrm{N}$, Kılıç D, et al. Chemical characterization of lavandula angustifolia mill. Which is a phytocosmetic species and investigation of its antimicrobial effect in cosmetic products. J Turk Chem Soc Sect A. 2017;4(1):283-98.

16. Yadikar N, Bobakulov K, Li G, Akber Aisa H. Seven new phenolic compounds from Lavandula angustifolia. Phytochem Lett. 2018;23:149-54. doi: 10.1016/j. phytol.2017.12.005.

17. Kamel M, Assaf M, Hasanean H, Ohtani K, Kasai R, Yamasaki K. Monoterpene glucosides from Origanum syriacum. Phytochemistry. 2001;58(8):1149-52.

18. Chen H-J, Inbaraj BS, Chen B-H. Determination of phenolic acids and flavonoids in Taraxacum formosanum Kitam by liquid chromatography-tandem mass spectrometry coupled with a post-column derivatization technique. Int J Mol Sci. 2011;13(1):260-85.

19. Pereira E, Antonio A, Barreira JC, Santos-Buelga C, Barros L, Ferreira IC. How gamma and electron-beam irradiations modulate phenolic profile expression in Melissa officinalis L. and Melittis melissophyllum L. Food Chem. 2018;240:253-8.

20. Lopes C, Pereira E, Soković M, Carvalho A, Barata A, Lopes V, et al. Phenolic composition and bioactivity of Lavandula pedunculata (Mill.) Cav. samples from different geographical origin. Molecules. 2018;23(5):1037.

21. 21. Bobro SG, Tikhonov OI, Blazheyevskiy MY. Quantitative determination of azelaic acid in "Propolis" gel with the propolis phenolic hydrophobic drug for treating acne J Pharm Pharmacol. 2015;3:73-9.

22. Song J, Zhang W, Sun J, Zhang X, Xu X, Zhang L, et al. Determination of salvianolic acid $\mathrm{C}$ in rat plasma using liquid chromatography-mass spectrometry and its application to pharmacokinetic study. Biomed Chromatogr. 2016;30(3):376-83.

23. Wang S, Liu L, Wang L, Hu Y, Zhang W, Liu R. Structural characterization and identification of major constituents in Jitai tablets by high-performance liquid chromatography/ diode-array detection coupled with electrospray ionization tandem mass spectrometry. Molecules. 2012;17(9):1047093.

24. Breton-Funes J, de Atauri IJR. Triterpenes from Lavandula canariensis. J Nat Prod. 1986;49(5):937-.

25. Tine Y, Renucci F, Costa J, Wélé A, Paolini J. A Method for LC-MS/MS profiling of coumarins in Zanthoxylum zanthoxyloides (Lam.) B. Zepernich and Timler extracts and essential oils. Molecules. 2017;22(1):174.

26. Politi M, De Tommasi N, Pescitelli G, Di Bari L, Morelli I, Braca A. Structure and Absolute Configuration of New Diterpenes from Lavandula multifida. J Nat Prod. 2002;65(11):1742-5.

27. Sosa S, Altinier G, Politi M, Braca A, Morelli I, Della Loggia R. Extracts and constituents of Lavandula multifida with topical anti-inflammatory activity. Phytomedicine. 2005;12(4):271-7.

28. Areias F, Valentão P, Andrade P, Moreira M, Amaral J, Seabra R. HPLC/DAD analysis of phenolic compounds from lavender and its application to quality control. J Liq Chromatogr Relat Technol. 2000;23(16):2563-72

29. Xia B, Bai L, Li X, Xiong J, Xu P, Xue M. Structural analysis of metabolites of asiatic acid and its analogue madecassic acid in zebrafish using LC/IT-MSn. Molecules. 2015;20(2):300119.

30. Zhang T, Chen S, Syed I, Ståhlman M, Kolar MJ, Homan EA, et al. A LC-MS-based workflow for measurement of branched fatty acid esters of hydroxy fatty acids. Nat Protoc. 2016;11(4):747.

31. Lee JW, Mok HJ, Lee D-Y, Park SC, Ban MS, Choi J, et al. UPLC-MS/MS-based profiling of eicosanoids in RAW264. 7 cells treated with lipopolysaccharide. Int J Mol Sci. 2016;17(4):508.

32. Natić MM, Dabić DČ, Papetti A, Akšić MMF, Ognjanov $\mathrm{V}$, Ljubojević $\mathrm{M}$, et al. Analysis and characterisation of phytochemicals in mulberry (Morus alba L.) fruits grown in Vojvodina, North Serbia. Food Chem. 2015;171:128-36.

33. Karar ME, Kuhnert N. UPLC-ESI-Q-TOF-MS/MS characterization of phenolics from Crataegus monogyna and Crataegus laevigata (Hawthorn) leaves, fruits and their herbal derived drops (Crataegutt Tropfen). J Chem Biol Ther. 2015;1(102).

34. Švehlíková V, Bennett RN, Mellon FA, Needs PW, Piacente S, Kroon PA, et al. Isolation, identification and stability of acylated derivatives of apigenin 7-O-glucoside from chamomile (Chamomilla recutita L. Rauschert). Phytochemistry. 2004;65(16):2323-32.

35. Brito A, Ramirez JE, Areche C, Sepúlveda B, Simirgiotis MJ. HPLC-UV-MS profiles of phenolic compounds and antioxidant activity of fruits from three citrus species consumed in Northern Chile. Molecules. 2014;19(11):17400-21.

36. Yang S, Wu X, Rui W, Guo J, Feng Y. UPLC/Q-TOF-MS analysis for identification of hydrophilic phenolics and lipophilic diterpenoids from Radix Salviae Miltiorrhizae. Acta Chromatogr 2015;27(4):711-28.

37. Pati S, Crupi P, Benucci I, Antonacci D, Di Luccia A, Esti M. HPLC-DAD-MS/MS characterization of phenolic compounds in white wine stored without added sulfite. Food Res Int. 2014;66:207-15.

38. Kajdžanoska M, Gjamovski V, Stefova M. HPLC-DAD-ESIMSn identification of phenolic compounds in cultivated 
strawberries from Macedonia. Maced J Chem Chem Eng. 2010;29(2):181-94.

39. Abu-Reidah IM, Ali-Shtayeh MS, Jamous RM, ArráezRomán D, Segura-Carretero A. HPLC-DAD-ESI-MS/ MS screening of bioactive components from Rhus coriaria L.(Sumac) fruits. Food Chem. 2015;166:179-91.

40. Areias F, Valentão P, Andrade P, Moreira M, Amaral J, Seabra R. HPLC/DAD analysis of phenolic compounds from lavender and its application to quality control. J Liq Chromatogr Rel Technol. 2000;23(16):2563-72.

41. Lee YH, Kim B, Kim S, Kim M-S, Kim H, Hwang S-R, et al. Characterization of metabolite profiles from the leaves of green perilla (Perilla frutescens) by ultra high performance liquid chromatography coupled with electrospray ionization quadrupole time-of-flight mass spectrometry and screening for their antioxidant properties. J Food Drug Anal. 2017;25(4):776-88.

42. Sharma GN, Gupta G, Sharma P. A Comprehensive Review of Free Radicals, Antioxidants, and Their Relationship with Human Ailments. Crit Rev Eukaryot Gene Expr. 2018;28(2):139-54. doi: 10.1615/ CritRevEukaryotGeneExpr.2018022258.

43. Elhassanny AEM, Ladin DA, Soliman E, Albassam H, Morris A, Kobet R, et al. Prostaglandin D2-ethanolamide induces skin cancer apoptosis by suppressing the activity of cellular antioxidants. Prostaglandins Other Lipid Mediat. 2019;142:9-23. doi: 10.1016/j.prostaglandins.2019.03.001.

44. Tian LL, Wang XJ, Sun YN, Li CR, Xing YL, Zhao HB, et al. Salvianolic acid B, an antioxidant from Salvia miltiorrhiza, prevents 6-hydroxydopamine induced apoptosis in $\mathrm{SH}$ SY5Y cells. Int J Biochem Cell Biol. 2008;40(3):409-22. doi: 10.1016/j.biocel.2007.08.005.

45. Yuan T, Chen Y, Zhang H, Fang L, Du G. Salvianolic Acid A, a Component of Salvia miltiorrhiza, Attenuates Endothelial-Mesenchymal Transition of HPAECs Induced by Hypoxia. Am J Chin Med. 2017;45(6):1185-200. doi:
10.1142/S0192415X17500653.

46. Al-Abbasi F, Alghamdi E, Baghdadi M, Alamoudi A, ElHalawany A, El-Bassossy H, et al. Gingerol synergizes the cytotoxic effects of doxorubicin against liver cancer cells and protects from its vascular toxicity. Molecules. 2016;21(7):886.

47. Solowey E, Lichtenstein M, Sallon S, Paavilainen H, Solowey E, Lorberboum-Galski H. Evaluating medicinal plants for anticancer activity. Sci World J. 2014;2014.

48. Amin A, Gali-Muhtasib H, Ocker M, Schneider-Stock R. Overview of major classes of plant-derived anticancer drugs. Int J Biomed Sci. 2009;5(1):1-11.

49. Ali MA, Abul Farah M, Al-Hemaid FM, Abou-Tarboush FM. In vitro cytotoxicity screening of wild plant extracts from Saudi Arabia on human breast adenocarcinoma cells. Genet Mol Res. 2014;13(2):3981-90. doi: 10.4238/2014. May.23.9.

50. Dalilan S, Rezaei-Tavirani M, Nabiuni M, HeidariKeshel S, Zamanian Azodi M, Zali H. Aqueous Extract of Lavender Angustifolia Inhibits Lymphocytes Proliferation of Hodgkin's Lymphoma Patients. Iran J Cancer Prev. 2013;6(4):201-8.

51. Wu CF, Karioti A, Rohr D, Bilia AR, Efferth T. Production of rosmarinic acid and salvianolic acid B from callus culture of Salvia miltiorrhiza with cytotoxicity towards acute lymphoblastic leukemia cells. Food Chem. 2016;201:292-7. doi: 10.1016/j.foodchem.2016.01.054.

52. Hao Y, Xie T, Korotcov A, Zhou Y, Pang X, Shan L, et al. Salvianolic acid B inhibits growth of head and neck squamous cell carcinoma in vitro and in vivo via cyclooxygenase- 2 and apoptotic pathways. Int J Cancer. 2009;124(9):2200-9. doi: 10.1002/ijc.24160.

53. Yin R, Li T, Tian JX, Xi P, Liu RH. Ursolic acid, a potential anticancer compound for breast cancer therapy. Crit Rev Food Sci Nutr. 2018;58(4):568-74. doi: 10.1080/10408398.2016.1203755. 